\title{
Use of the 3-D scanner in mapping and monitoring the dynamic degradation of soils: case study of the Cucuteni-Baiceni Gully on the Moldavian Plateau (Romania)
}

\author{
G. Romanescu ${ }^{1}$, V. Cotiuga ${ }^{2}$, A. Asandulesei ${ }^{2}$, and C. Stoleriu ${ }^{1}$ \\ ${ }^{1}$ Alexandru Ioan Cuza University of Iasi, Faculty of Geography and Geology, Department of Geography, Bd. Carol I, 20A, \\ 700505 Iasi, Romania \\ ${ }^{2}$ University of Iasi, ARHEOINVEST Laboratory, Bd. Carol I, 11, 700506 Iasi, Romania
}

Correspondence to: G. Romanescu (geluromanescu@yahoo.com)

Received: 10 July 2011 - Published in Hydrol. Earth Syst. Sci. Discuss.: 14 July 2011

Revised: 22 January 2012 - Accepted: 20 February 2012 - Published: 22 March 2012

\begin{abstract}
The 3-D scanner, a rapid and precise means of monitoring the dynamics of erosive processes, was first used nationally (Romania) as a new technique of cartography and monitoring the dynamics of soil degradation processes in the Moldavian Plateau. Three sets of measurements took place: in 2008, in 2009 and in 2010, at intervals of exactly one year for the first and six months for the second part. Qualitative and quantitative differences were highlighted. The data obtained were corroborated with precipitation in the area studied. The 3-D scanner has a measurement accuracy of $6 \mathrm{~mm}$. The map highlights the dynamics of gullies developed and may form the basis for the prediction of soil degradation phenomena. The dynamics of the gully and the type of land use show that the phenomenon of erosion of the Moldova Plateau will continue to accelerate. In this case, the gully attacked and destroyed an archaeological site of national importance. The rate of advance of the Cucuteni-Baiceni gully is extremely high $(10 \mathrm{~m} / 1.6$ years $)$. There are no measures at all to reduce or fight the process of the gully advance. Maximum erosion occurred at the beginning of spring after a winter rich in rainfall, which made the terrain subject to the process of subsidence.
\end{abstract}

\section{Introduction}

To analyze the morphological and dynamic geomorphological slope process, a variety of modern methods have been used so far. They have not, however, been used frequently, and have not been very accurate. In most studies, rough traditional methods have been used, based on wood or metal markers. In this study, for the first time in Romania, and also on a global scale, a 3-D scanner was used in the mapping of gullies. The dynamics of the geomorphological processes of soil erosion were followed in detail. Specialized institutions closely followed the geomorphological processes that actively show the whole of the Moldova Plateau, but unfortunately, inadequate instruments were used and the results were not satisfactory. By using a 3-D scanner, many of the expected responses will provide accurate, dynamic geomorphology and a much-improved database.

This study will develop on the dynamics of gullies of the Moldavian Plateau, and develop a specific methodology and 3-D scanner to obtain accurate data, in millimeters or centimeters, about the changes that may occur in very short periods of time. Correlation of 3-D scanner data with those obtained via traditional methods will certainly improve the methods of preventing and combating the risk of geomorphological phenomena. At the same time, it seeks to use the technique to be implemented in as many areas of investigation as possible: geomorphology, archeology, agronomy, protection of the environment, land management, etc.

The use of a 3-D scanner to monitor the morphometric development of a gully is, undoubtedly, the most accurate method that can be employed for such undertakings, namely the monitoring of soil degradation phenomena (Lane, 2008). Such an endeavor has never been accomplished before in Romania, while abroad, the 3-D scanner has started to be used only relatively recently for monitoring soil degradation caused by gullying, and it is still in the trial-and-error stage.

The investigation of the gully is of particular importance because it is extremely active, and its development affected 


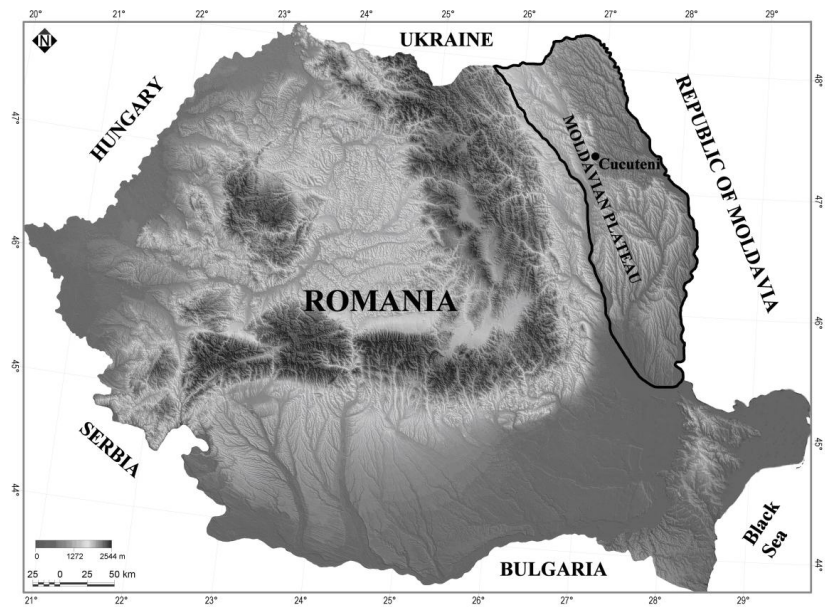

Fig. 1. The geographical location of the Cucuteni-Baiceni gullies and plateau in Romania and Moldova.

the Cucuteni archaeological site, the eponymous settlement of the famous Neolithic culture. For a good correlation with the data previously obtained and a full analysis of morphological traits (morphography and morphometry) in specific gullies, wide-ranging international and national sources have been consulted: Bacauanu, 1968; Barnoals et al., 2010; Blong et al., 1982; Böhler and Marbs, 2006; Bornaz and Rinaudo, 2004; Bradford et al., 1978; Bretar et al., 2009; Bull and Kirkby, 1997; Casas et al., 2010; De Oliveira, 1990; Ernst et al., 2010; Harvey, 1992; Heede, 1976; Ionita, 2006; James et al., 2007; Kern, 2002; Lane, 2008; Leica HDS3000 data sheet, 2006; Milan et al., 2007; Perroy et al., 2010; Phillips, 2006; Radoane et al., 1995, 1999, 2009; Vandaele et al., 1996; Vosselman and Dijkman, 2011.

\section{Regional setting}

The Moldavian Plateau is the largest and most representative of Romania's plateaus (Bacauanu, 1968). It spans the eastern part of the country, most of the Republic of Moldova, and the Chernivtsi Oblast of Ukraine. The Romanian section is bounded by the Ukrainian border to the north, the valley of the Prut River to the East, the Romanian Plain and the Danube to the South, and the Eastern Carpathians to the West (Fig. 1).

A landscape including the Carpathians and the Danube characterizes part of the great stage of hilly lands (Romanescu et al., 2008). It has a total area of $25000 \mathrm{~km}^{2}$, over $10 \%$ of the territory (Romanescu, 2009; Romanescu and Nistor, 2011; Romanescu et al., 2011a,b).

The gully scanned in 2008, 2009 and 2010 is located in the southwestern Plains of Moldavia, a subdivision of the Moldavian Plateau relief. It cuts off the right side of the Cucuteni brook $\left(13 \mathrm{~km}^{2}\right.$ catchment area and $11 \mathrm{~km}$ long), left tributary of the Bahluiet $\left(551 \mathrm{~km}^{2}\right.$ catchment area and $41 \mathrm{~km}$ long).

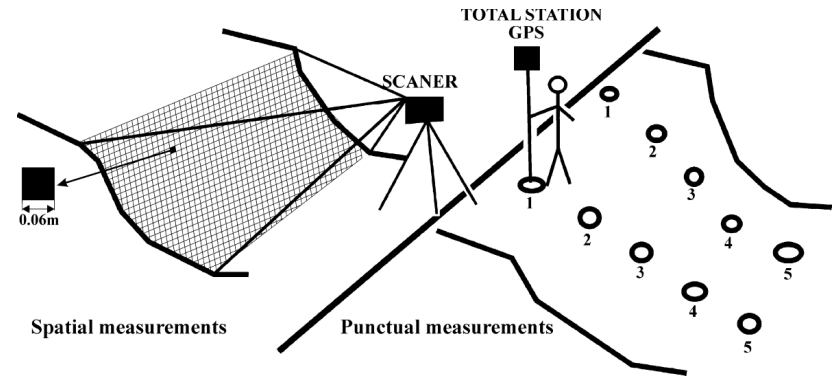

Fig. 2. The spatial measurements using the 3-D scanner and the punctual measurements using the Total Station and GPS.

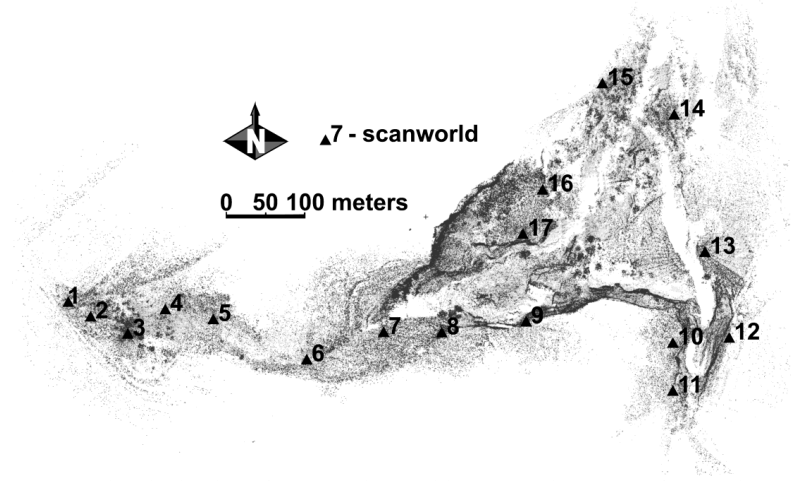

Fig. 3. The spatial distribution of the scanning positions around the edge of the gully.

The Moldavian Plateau is a large relief unit affected by land degradation processes, especially surface erosion, deep erosion and landslides (Radoane et al., 1995, 2009). Across the Moldavian Plateau, there are two important areas prone to gullying: the southern half of the Moldavian Plain in the North-East and in the South-East (the middle section of the Jijia River, the upper basin of the Bahluiet), and the southern half of the Barlad Plateau (Falciu Hills, Tutovei hills, Covurlui Plateau) (Ionita, 2006). The lower density gullies in the Central Moldavian Plateau area is due to the presence of sandstone and limestone plate and a high level of afforestation.

From the geomorphological point of view, the gully from Cucuteni-Baiceni has the following typology: a longitudinal profile form: continuous, as the plan configuration (two points of origin) or front (the bank); after locating in the basin: the slope; by form of cross-section: the shape of "V"; after the development cycle: perennial (with banks).

\section{Materials and methods}

For measurements of the morphometrical parameters of the Cucuteni-Baiceni gullies, the Leica 3-D scanner was used. Up to now, this device had been used in architecture, 


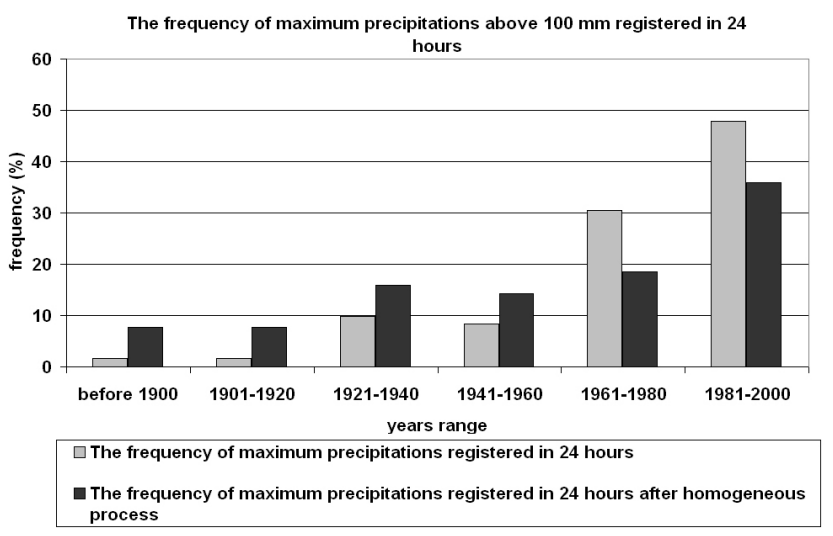

Fig. 4. The frequency of maximum precipitation above $100 \mathrm{~mm}$ registred in $24 \mathrm{~h}$.

archeology, etc. (Barnoals et al., 2010; Bitelli et al., 2011; Xie and Jia, 2010; Bornaz and Rinaudo, 2004; Lee and Schenk, 2001; Marzolff and Poesen, 2009; Mikoš et al., 2005). As a result of its performance, it can be used successfully to assess the state of the environment, especially in land mapping and measuring the rate of erosion in some land surfaces with limited extension (Böhler and Marbs, 2006; Bretar et al., 2009; Leica HDS3000 data sheet, 2006).

The working principles of a 3-D scanner are identical to those of a total station. It relies on registering distances and angles, and the data thus produced is used to compute the points' coordinates. The ability to register a massive amount of 3-D information in a relatively short time is the main advantage of this instrument, in contrast to classical equipment such as the total station (Kern, 2002; Milan et al., 2007) (Fig. 2). Terrestrial laser scanning (TLS) generates several point clouds, with local coordinates and additional information (the light intensity in the reflected beam, and the RGB values obtained from an external or internal photographic camera). The point clouds, after having been registered from different positions, must be merged as to obtain a complete model of the scanned target. This procedure is called "registration" and involves the merger of the point clouds through the use of refractive tie-points, specially built and delivered by the manufacturer, which are automatically recognized by the scanner when a very fine scan is performed.

For the current project, in all of the three scanning episodes, we made use of a Leica ScanStation HDS 5600 3D scanner. It is a time-of-flight active scanner, which works by timing the round-trip time of a pulse of light. The operation range is $270^{\circ}$ horizontally and $360^{\circ}$ vertically, and the active distance is $300 \mathrm{~m}$. With a resolution of $6 \mathrm{~mm}$ at a distance of $50 \mathrm{~m}$, and because of the ability to register approximately 4000 points per second, the ScanStation HDS scanner is among the most productive equipment of its kind.

The use of 3-D scanning, particularly when dealing with a gully of striking dimensions and irregular surfaces, as is

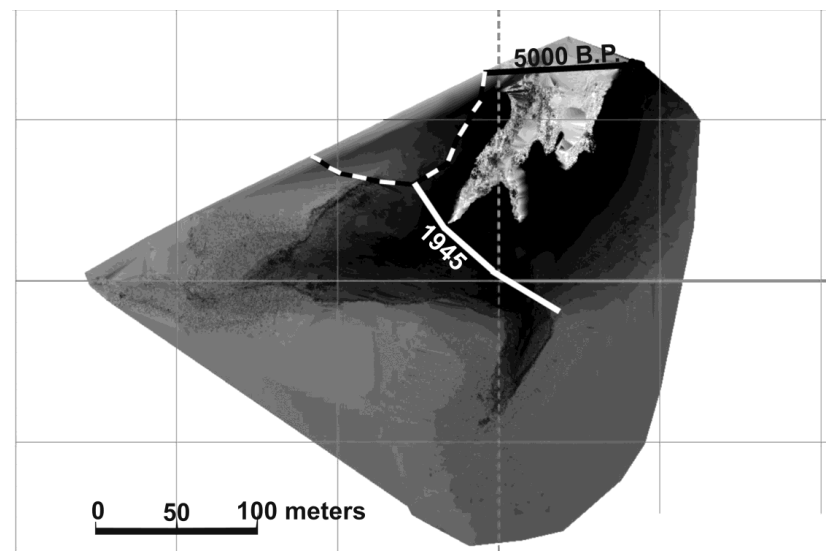

Fig. 5. Three-dimensional and mapping model of the CucuteniBaiceni gully in 2008. The position of the archaeological site and the limits of the gully $5000 \mathrm{BP}$ and 1945 (main active channel).

the case at Cucuteni-Baiceni, requires increased attention to selecting the scanning positions. Their defective field deployment can cause the omission of some areas from within the targeted area and low accuracy, which implicitly leads to major flaws of the final tri-dimensional model. Because of the relatively wide area of study, we were forced to use 17 scanning positions (Fig. 3), thus covering the investigated landform in its entirety; most of them were the same for all of the three scanning sessions. The spatial distribution of the scanning positions was in most cases around the edge of the gully, and few from within it. To merge the 17 positions, 6 refractive tie-points were used for each of them, save the last. Nonetheless, for the entire model we used 24 tie-points, since some of the scanning positions were referenced, where the physical distance allowed us to tie-points also used by other scanning positions.

The average resolution for all of the scans was of approximately $6 \mathrm{~mm}$, and the registered points numbered millions, despite the fact that the majority of positions overlapped. Although an external photographic camera can be attached to the scanner, we did not considered it to be better suited for the task than the internal camera (James et al., 2007).

A particularly important phase of the fieldwork facet of the project was the geo-referencing of the point clouds. Using a reference station positioned on a fixed known spot and a Leica 1200 GPS, we referenced the point cloud we considered the basis for the 3-D model to the national coordinates system (Stereographic, 1970). In fact, our work methodology was based, for all of the three sessions, on computing the differences between the obtained geo-referenced models using CAD and GIS.

In respect to the processing of the raw data, this was done by filtering the data using the Cyclone dedicated software program, registering the data (see above), reducing the point cloud, creating a mesh by triangulation, and texturing the model. 


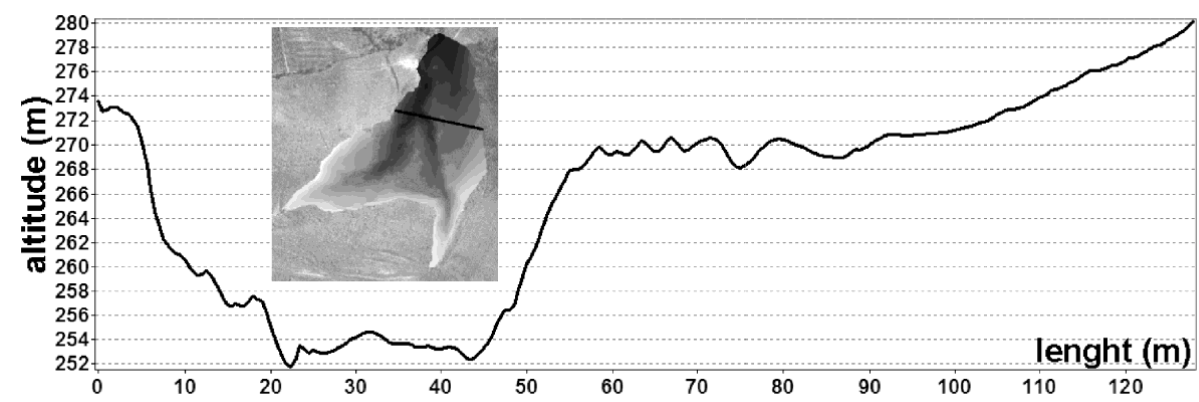

Fig. 6. Morphometric characteristics of the Cucuteni-Baiceni gully.

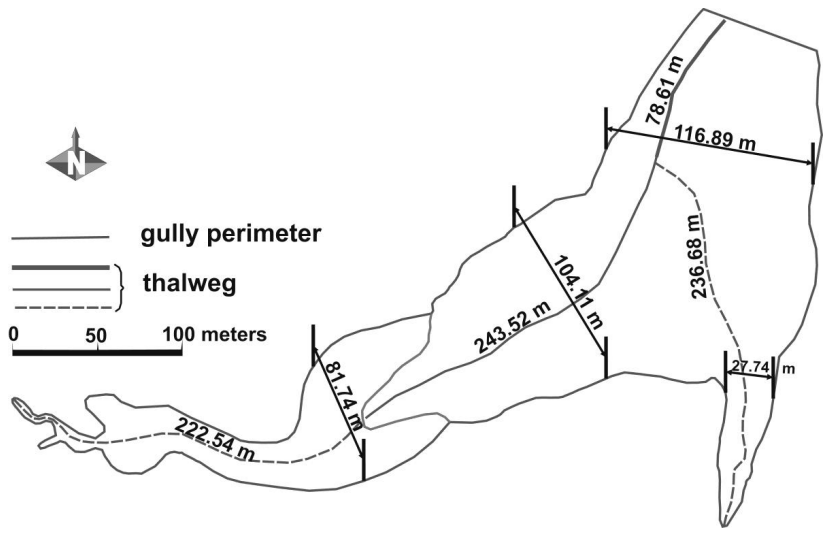

Fig. 7. Longitudinal profiles of surface and principal gullies on the Cucuteni-Baiceni side gullies in 2008.

The final results of the study were produced by exporting sections, transverse and longitudinal, of the three tridimensional models obtained in each session.

Furthermore, for increased accuracy, the edge of the gully was delimited, during each session, using the two "traditional" instruments mentioned above (the reference station and the 1200 GPS, both produced by Leica). The operation was somewhat cumbersome, because in such cases the data must be collected from extremely numerous positions, as to take into account all of the inflexions (Kern, 2002; Milan et al., 2007). All of the positions were geo-referenced and confronted to older measurements. In this way, we were able to estimate the rate of soil erosion in the gully, for each of the measurements taken. The co-joint use of these two types of measurements (GPS and 3-D scanner) means that the risk of error was much diminished.

The Cucuteni-Baiceni gully was selected for the present research because it is extremely active. The area occupied by the gully is very sparsely covered by vegetation, and the trees are virtually absent; therefore, nothing prevented volumetric measuring. The very sparse shrub vegetation was removed using the techniques made available by the dedicated software. The reason behind the selection of the gully for our investigation was due to the fact that the gullying process has

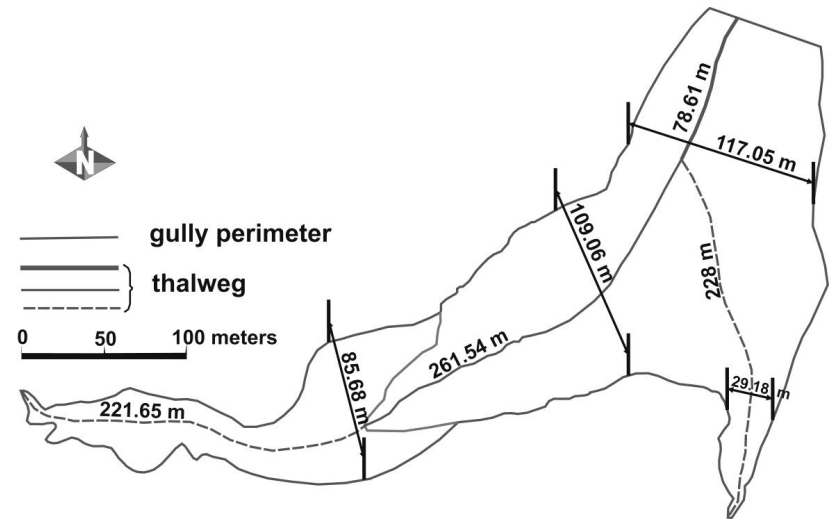

Fig. 8. Morphometry of the Cucuteni-Baiceni gullies in 2010.

affected a very important archaeological site dating back to circa $5000 \mathrm{BP}$. This made it easier to assess the rate of erosion over a period of great lengths.

Three consecutive measurements were performed at relatively equal intervals in 2008, 2009 and 2010. The last measurement was made in spring 2010 after a solid winter precipitation and high rainfall in spring. For the historical evolution of gullies, topographic maps and military plans of the Romanian Army were consulted. During the Second World War the Army had placed a battery of guns in the area of the unit studied. Unfortunately, it has only been possible to make use of land-use maps since 1950. Those developed before these years are not accurate and they are often for orientation only, with a high degree of generalization.

Meteorological data on precipitation, daily and monthly, were provided by the Meteorological Centre, Iasi, Moldavia. They were focussed on Cotnari Meteorological Station, located near the Cucuteni-Baiceni gullies. The most important stations were rather uniformly distributed on Moldavian territory (Eastern Romania). 


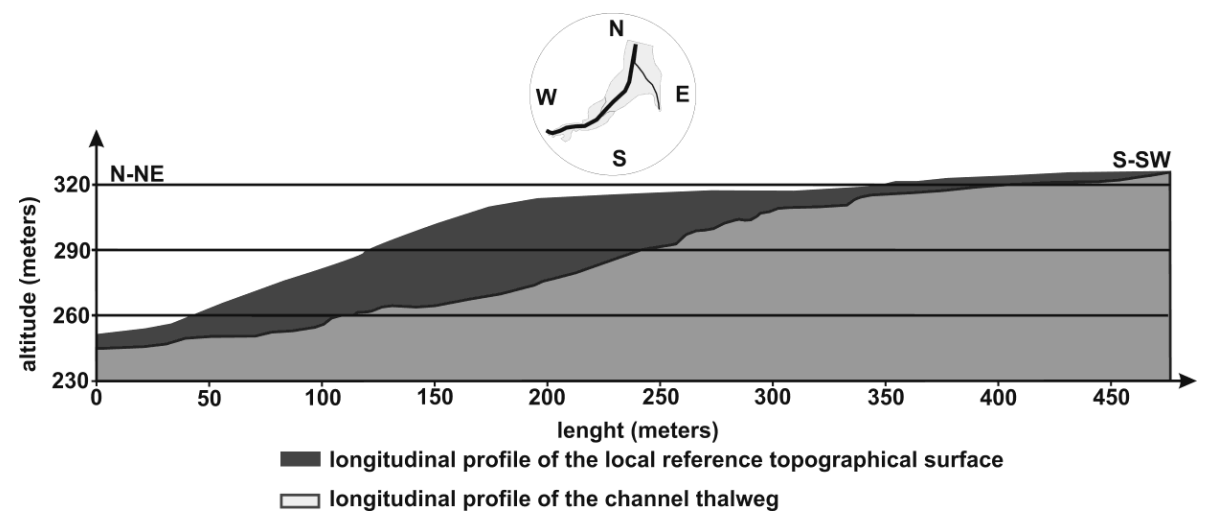

Fig. 9. Longitudinal profiles of all the surfaces and talwegs of the main Cucuteni-Baiceni gullies in 2008.

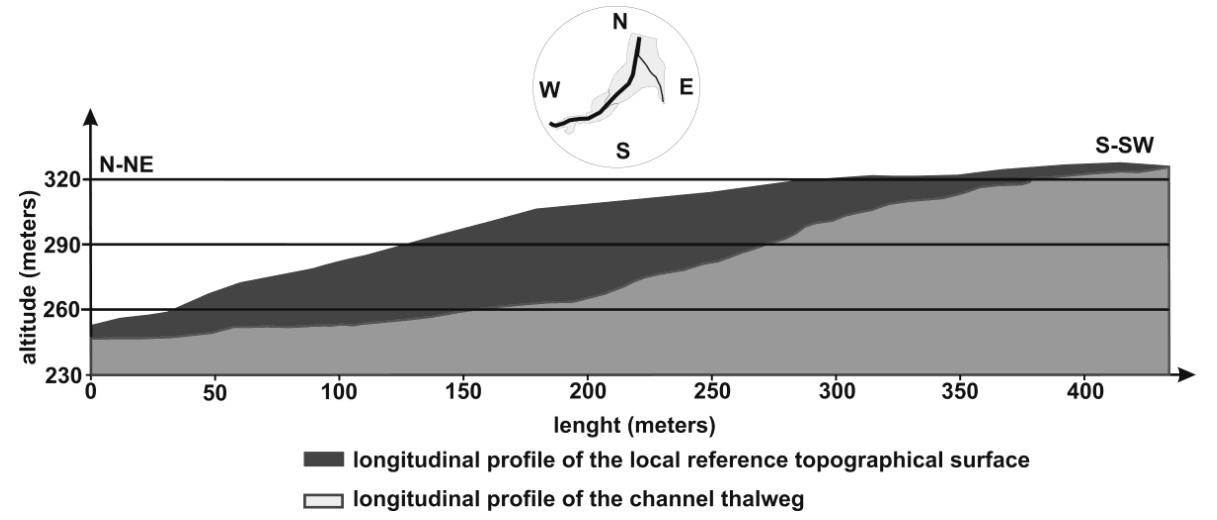

Fig. 10. Longitudinal profiles of surface and river bed of the main Cucuteni-Baiceni gullies in 2010.

\section{Results and discussions}

Erosion gullies are deep, cut from loose rocks. They consist of a channel with steep banks and talweg thresholds (with a cross-section greater than $1000 \mathrm{~cm}^{2}$ ), a threshold of spring water that often flows ephemerally and a longitudinal profile as a powerful curved parabol (De Oliveira, 1990; Harvey, 1992; Phillips, 2006; Vandaele et al., 1996). The CucuteniBaiceni gully is representative from a morphological and dynamic point of view. Selected for a prolonged monitoring from the beginning of 2008, it is located near the most important chalcolithic archaeological site on the territory of the Moldavian plateau, and affects its integrity. Citadel Hill remains of the Cucuteni culture were discovered, unique in Europe (Boghian, 2004; Ursulescu, 2006; Cotiuga and Cotoi, 2006).

On the territory of the Moldavian Plateau, 9000 ravines have been inventoried. Microform relief leads to significant losses of soil and causes mal gravitational processes (Radoane et al., 1999). Gullying processes triggering causes are found primarily in the nature of the geological substratum of the landscape, climate change, pollution phenomena and anthropogenic interventions (Blong et al., 1982; Casas et al., 2010; Ernst, 2010; Heede, 1976).

The gullies of the Moldavian Plateau made a strong debut, whose date was determined to be 1828 , when deforestation corresponded to the centre of these massive relief units. It seems that the afforestation rate in 1832 was across the entire plateau of over $47 \%$. In 1893 it amounted to $21.9 \%$ (Poghirc, 1972). The development of forests in the nineteenth century was strongly influenced by land laws in the years 1828, 1842, 1864, 1877 and 1881. Stepping gullies in recent years has been due to poor road infrastructure and inadequate agricultural techniques. To these must be added the Land Law of 18/1991, which led to a strong fragmentation of arable land properties, and whose effect was almost entirely oriented towards the hill-valley direction.

Specific linear erosion of the gullies occurs when surface flow is concentrated in a context of increasing kinetic energy of liquid flow resistance and a decrease of the substrate or protective coating plant (Bradford et al., 1978; Bull and Kirkby, 1997; Ionita, 2000). In the Moldovian Plateau the critical season for gullying was set for 15 to 20 March and 15 to 20 July (Ionita, 2000, 2006). This role took it to the 


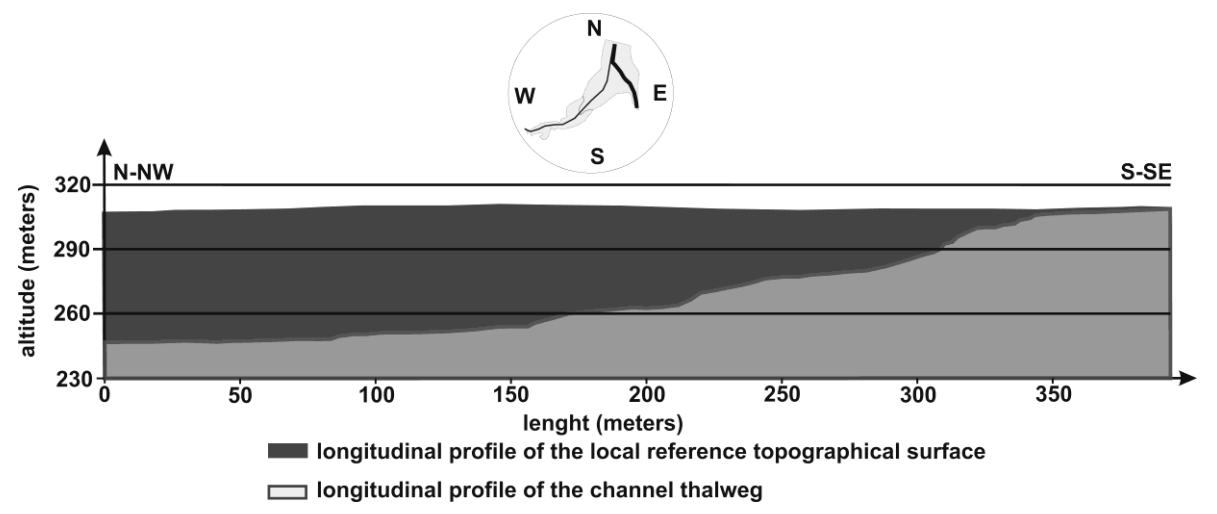

Fig. 11. Longitudinal profiles of surface and river bed Cucuteni-Baiceni side gullies in 2008.

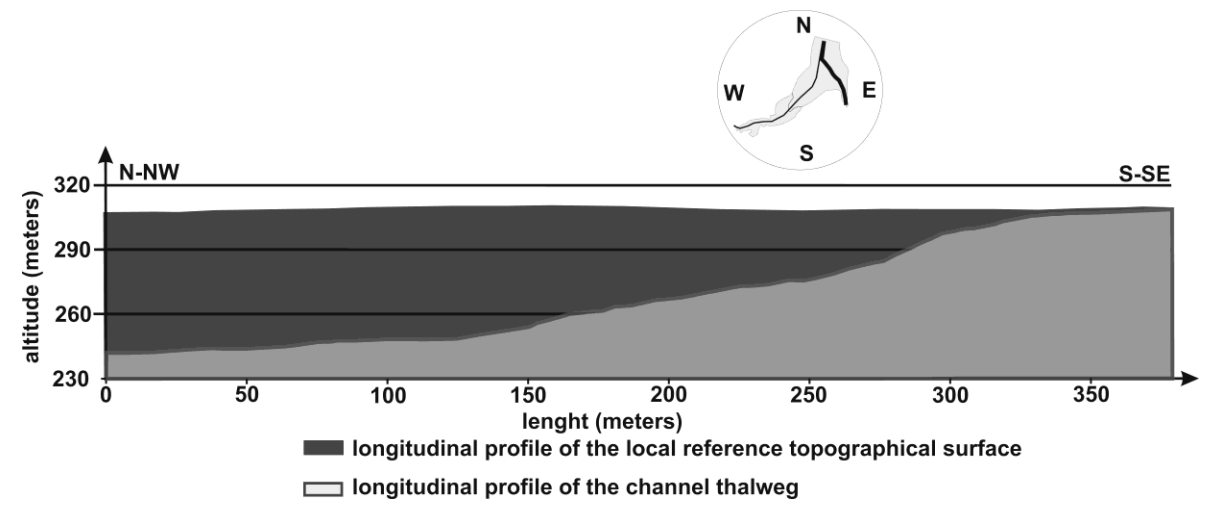

Fig. 12. Longitudinal profiles of the surface and river bed Cucuteni-Baiceni side gullies in 2010 .

cold season (57\%), while forming $43 \%$ of the hot season. In fact, the material was prepared by the winter freeze-thaw phenomena. This case is due to the strong brittle substrate of the gully (loess, clay, sand, sandstone, etc.) slope and special hydroclimatic conditions (Bacauanu et al., 1980; Branzila, 1999). Recent years have seen increasingly more frequent and torrential spring rains, with amounts that sometimes exceed those of the summer. At the same time strong erosion of the spring coincides with a field devoid of vegetation, and at the same time ploughed, in preparation for sowing.

The Moldavian Plateau, with its extra-Carpathian position is temperate continental with some excessive nuances. For $\mathrm{W}$ and NW a moderate continental climate characteristic of western continental interferes (Pantazica, 1974). The most characteristic of the Eastern European influences are the imprinted predominance of cold air masses during the winters and hot and dry summers. Annual average temperatures have values of $7.5-10^{\circ} \mathrm{C}$, with variations increasing in the N-S direction. Rainfall is between $500-700 \mathrm{~mm}$, with lower values in the lower, southern sectors.

Climatic nuances are caused by latitude and altitude of the mountain chain shelter. Suceava Plateau has a colder climate, rich in moisture in NW Europe due to cyclonic influences. On the Barlad plateau continental influences are felt to generate large thermal contrasts. Cold winters, dry summers and snow storms with torrential rain are characteristic of the invasion of continental air in the Moldavian Plain (Erhan, 2001).

Between 1 October 2008 and 31 October 2009, the first measurements were taken. The amount of precipitation which fell at Cotnari station was $569.4 \mathrm{~mm}$. The maximum amount of precipitation which fell within the range observed is relatively low. For erosive phenomena in the gullies, torrential rains, always present in this area, are very important. The largest amounts of precipitation were recorded on 12 February 2009 (21.8 mm), 3 August 2009 (16.7 mm), 6 March 2009 (30.8 mm), 25 June $2009(24.2 \mathrm{~mm})$, 29 June $2009(41.4 \mathrm{~mm}), 13$ July $2009(18.8 \mathrm{~mm}), 13$ October $2009(16.8 \mathrm{~mm})$. Quantities exceeding $20 \mathrm{~mm}$ in $24 \mathrm{~h}$ occurred during the summer (June-July) when the vegetation is relatively dry and soil will be eroded easily. Under normal precipitation, with averages of about $600 \mathrm{~mm} \mathrm{yr}^{-1}$, the gully shows reduced dynamics. In the first year of monitoring, rainfall was below the annual average of the location. In this case, the changes were minor. In the remaining six months of monitoring, the quantity of precipitation amounted to $263.9 \mathrm{~mm}$ (November 2009-April 2010). An important factor was that this amount of water was stored in its entirety 


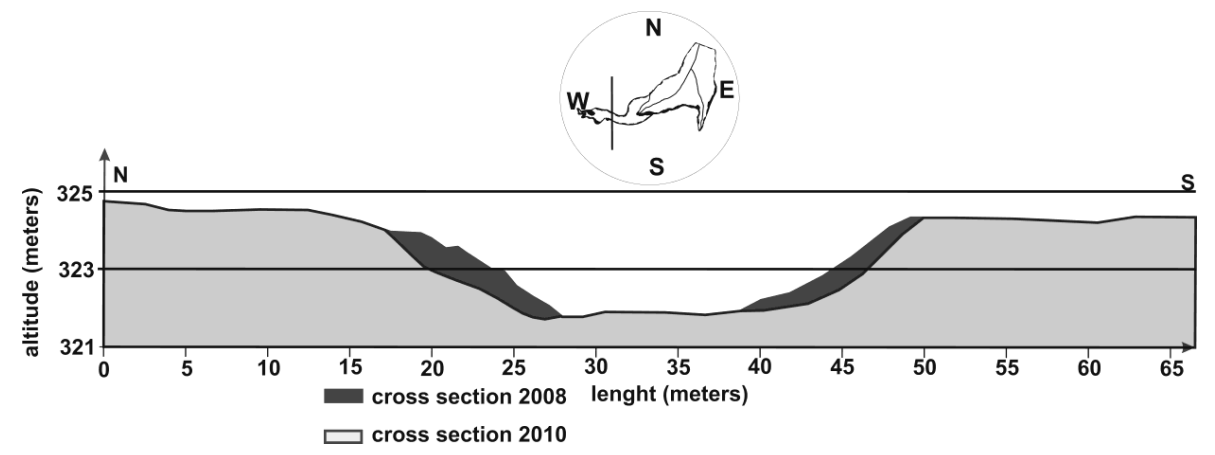

Fig. 13. Cross-section in the upstream of the main gullies.

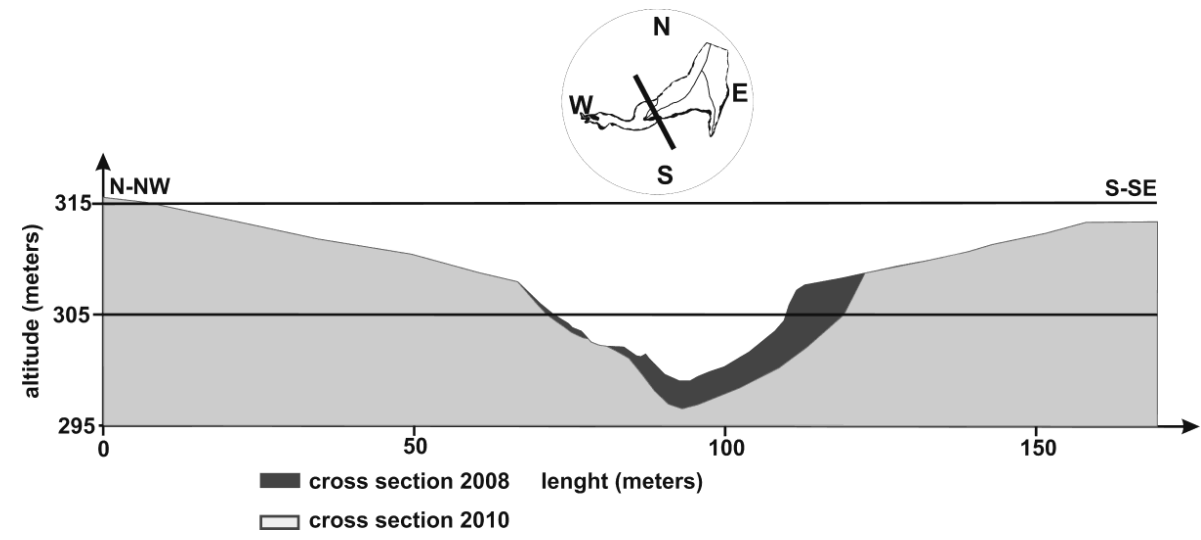

Fig. 14. Cross-section upstream of the gullies in the main high erosion activity.

as a layer of snow, favoured by very low winter temperatures. Melting of snow and the large amount of precipitation that fell in April 2010 (65.9 mm) made dynamic gullies react extremely rapidly. For this reason the measurement was made as number three, immediately after the collapse of the large central wall of gullies.

Deforestation and the felling of the forest led to important changes in the characteristics of the general climate in eastern Romania (Siret and Prut river basins), especially, increasing the tendency of torrential rains as well as growing aridity. Rainfall frequency values of more than $100 \mathrm{~mm} / 24 \mathrm{~h}$ increased from 1.7 before 1900 to 47.9 in the period 19812000. After homogenization of the data (adjusted values as a result of the increased number of hydrometric posts), percentages have changed: by 7.7 before 1900 to 35.9 between 1981-2000 (Fig. 4). After 2000 there were common values of $200 \mathrm{~mm} / 24 \mathrm{~h}$, especially during the floods of 2004, 2005, 2006, 2008 and 2010 (Plesoianu and Olariu, 2010). However, deforestation was required and therefore the need for land suitable for grazing animals.

In the gullies, geomorphological processes are dominant in the vegetation (collapses, landslides, surface runoff, muddy surface run-off, bad-land-measures, etc.) as well as longitudinal transport. The peaks are the most dynamic sections of the entirety of the gullies. Typically, the ratio between the bank and the processes of longitudinal transport ranges from 0.1 to 10 (between 1-10 in excess of 50\%). Overall, the processes which contribute to shore erosion gullies are 1-5 times more than the processes of deepending. The average rate of advancement of gullies in the Moldavian Plateau, from the empirical data analyzed, indicates a value of $1.5 \mathrm{~m} \mathrm{yr}^{-1}$ (Radoane et al., 1995). In the case of the Cucuteni-Baiceni ravines, two empirical evaluations can be made. According to military plans made in the course of the Second World War, the central cornice, between the two branches of the ravines, was located about $40 \mathrm{~m}$ outside (Fig. 5). For a period of 65 years, this resulted in an average rate of erosion of $0.61 \mathrm{~m}$ per year. If gullies relate to the main peak, the central cornice lies at a distance of about $200 \mathrm{~m}$. In this case, the average erosion rate was $3 \mathrm{~m}$ per year (with reference to the main active channel) or $6.48 \mathrm{~m}$ per year (with reference to the secondary channel). The second assessment related to a period of more than 5000 years, when the settlement was located on the outskirts of the $\mathrm{Cu}$ cuteni forested slope in the form of gullying. At this scale, the erosion rate was $0.07 \mathrm{~m}$ per year $(340.15 \mathrm{~m})$ or $0.11 \mathrm{~m}$ per year $(561.80 \mathrm{~m})$. This figure may not be relevant, because we do not have the necessary data to indicate times of 


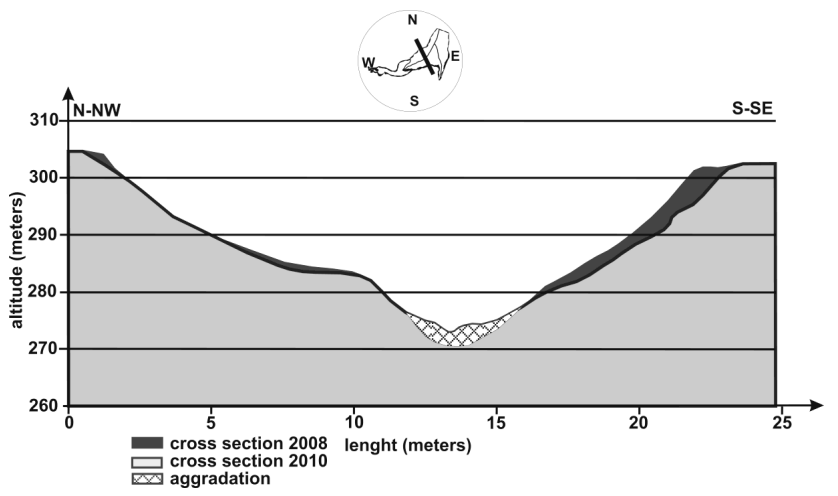

Fig. 15. Cross-section of the main gullies in the downstream.

deforestation and the changing use of land. However, deforestation was required in view of the need for land suitable for grazing animals.

Eastern Romania (or the region of Moldavia as it is known), under the influence of a continental climate with excessive nuances, soil erosion has high values. Of the multiple causes, two are crucial: torrential rains and massive deforestation occurring in 1990 (the year which coincides with land disposal to former owners). For this reason, linear erosion was not uniform or rhythmic, but created phenomena related to the production of high-risk disaster. Values of the erosion of 5-10 $\mathrm{m}$ per year were registered with the phenomena of powerful thunderstorms. In normal years in terms of rainfall, with rain falling throughout the year in a relatively uniform fashion, erosion is reduced.

The versants of the main gully are expanding in a nonuniform fashion: the steeper left versant suffers from major gravitational collapses, while the right one from gradual collapses, specific to loess deposits (Fig. 6).

Between 2008 and the measurements of the 2010 bank, radical changes occurred between the two branches of the gullies, the position of the riverbed and the length of the two branches (Figs. 7 and 8).

Talweg gullies extended along the main route by about $7 \mathrm{~m}$ due to regressive erosion. The equilibrium profile was altered by drawing convex curves. Talweg gullies with $7.68 \mathrm{~m}$ sides were shortened by reducing the drifting index. The junction point is relatively stable because the material was deposited as a result of erosion occurring within gullies. In this case the talweg joint remained at a value of $78.61 \mathrm{~m}$.

In the main gully, significant changes in the longitudinal profile took place through erosion or the deposit of brittle material (Figs. 9 and 10). A strong reduction of thresholds and increased convexity can be observed. The phenomenon is due to erosion, given the prominence of the areas and the deposit of material on the gentle slope.

Altitude, gully, and outlet head remain, in principle, at the same rate.

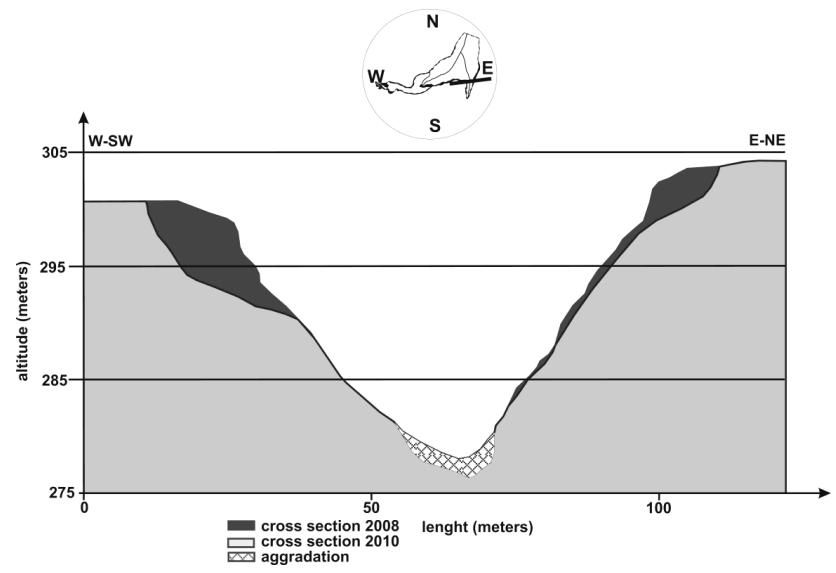

Fig. 16. Cross-section of the main gullies in the downstream.

The changes were produced in the longitudinal profile of the weaker side gullies for precedence, but were important for their relatively small size (Figs. 11 and 12).

Altitude, head left-side gullies, took place, in principle, at the same rate. However, the outlet is located at a higher rate because the amount of material transported, following a pronounced slope, is high.

Obvious changes are seen in the transverse profiles, especially at the points threshold (Figs. 13-16). In areas upstream at the end of the two gullies (primary and secondary), there are relatively minor changes to the common outlet. The slight widening of the heads of gullies is noted, while the mouth shows minor lifting.

The strongest erosion occurs on the right bank of the main gullies at the junction with the secondary gully, where the slope is steep. In this case, the withdrawal is about $10 \mathrm{~m}$. The average of $7.5 \mathrm{~m}$ per year is explained by the high friability of the rock, high slope and large amount of precipitation during the winter of 2009-2010. In 2008-2009, when precipitation was within the normal intervals, erosion gullies amounted to values below $1 \mathrm{~m}$ per year. As the average values were exceeded, especially during increased frequency and intensity of rainfall values over $20-50 \mathrm{~mm} / 24 \mathrm{~h}$, erosion increased exponentially. Therefore, the average represents a long reality with complex phenomena. Sequential, erosive situations are totally different.

In the bottom of the main, gullies occur due to a strong phenomenon an attractively high quantity of material moved, but not removed within gullies (Fig. 17). For secondary gullies, significant changes are noted on the slopes, in the thalweg. Dislodged material is found, for the most part, within its own valley.

The Cucuteni-Baiceni sector outlet of gullies provide a relatively stable area, because of the loose material deposited inside the valley. It will be able to be freed when the threshold of accumulated material is diminished by the outlet of materials deposited behind it. 


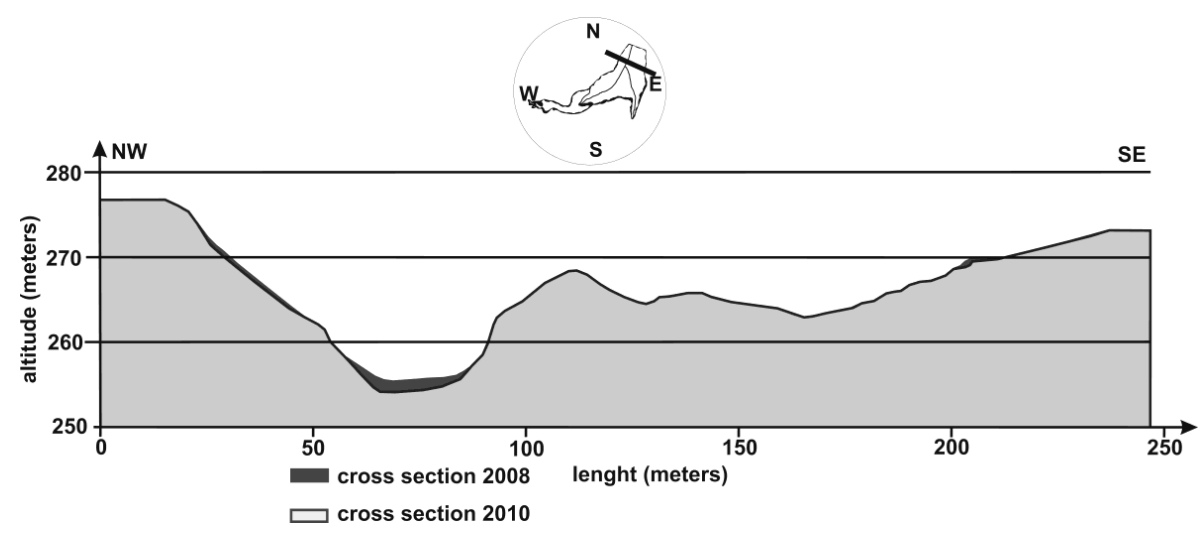

Fig. 17. Cross-section of the Cucuteni-Baiceni outlet gullies.

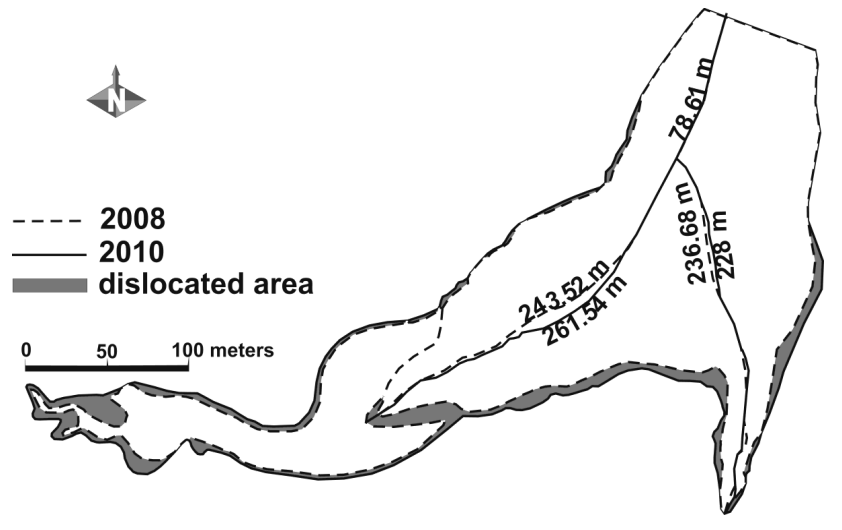

Fig. 18. The areas of separation and change in the Cucuteni-Baiceni river bed in the gully (2008-2010).

The three-dimensional model and maps are made using a highly accurate $3-\mathrm{D}$ scanner $(6 \mathrm{~mm} / 6 \mathrm{~mm}$ fidelity) and can be executed at the desired scale, depending on the requirement. To implement equidistant contour maps at $1 \mathrm{~m}$, parasites also appear which represent vegetation or bodies placed there by man. These obstacles were removed using software filters. In this case, they may have a higher accuracy. The measurement carried out using the 3-D scanner is more accurate and faster than anything carried out using Total Station or other tools. The most important issue is related to the georeferenced points, which were surveyed in their dynamics, especially due to the intense activity of the gully. Measurements must be repeated frequently to monitor reality more closely.

It can be noticed that among the three measurements taken at an interval of exactly one year, and then six months, that the strongest erosion occurred at the end cornices between the side gullies (Fig. 18). Lateral erosion occurs predominantly on the "minor bed" sides of gullying on the slopes which are themselves very low, and now covered with herbaceous vegetation. The collapse occurred in the largest sector of the two branches of the gullies, where the bank is steep

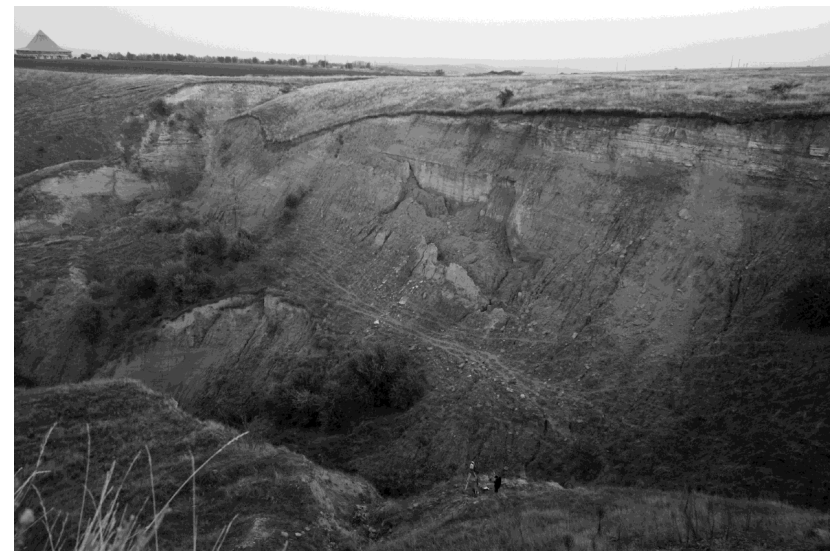

Fig. 19. The Cucuteni-Baiceni Gully.

and lacking support. Fouling occurs directly in the bed of the gully which therefore abruptly changed its position. The outlet of the gullies was practically alluvial and the loose material inside stagnated. Sedimentation of the riverbed is specific between the two side arms. Extending upstream in two arms, different attractive outlets are visible, with values ranging between $20-25 \mathrm{~cm}$ and $1 \mathrm{~m}$. This is due to the heavy rains in the period analyzed. They were appropriately strong and fell during summer. This area is conducive to high erosion.

Withdrawal from the cornice by the stronger of the two branches of the gully was due to the collapse of the slopes. Accumulation of material was based on the bank, on the interfluve. The withdrawal amount was well above average and the forecast for the large gullies of the Moldavian Plateau indicates a permanent withdrawal on the same alignment. The high value of the accretion is due to the collapse of a vertical wall which lacked physical support. This sector is situated between the two secondary arms of the gully. The large volume of deposited material was caused by the high precipitations which broke whole packets of material from the lateral walls. These breakings are specific to loess packets. 


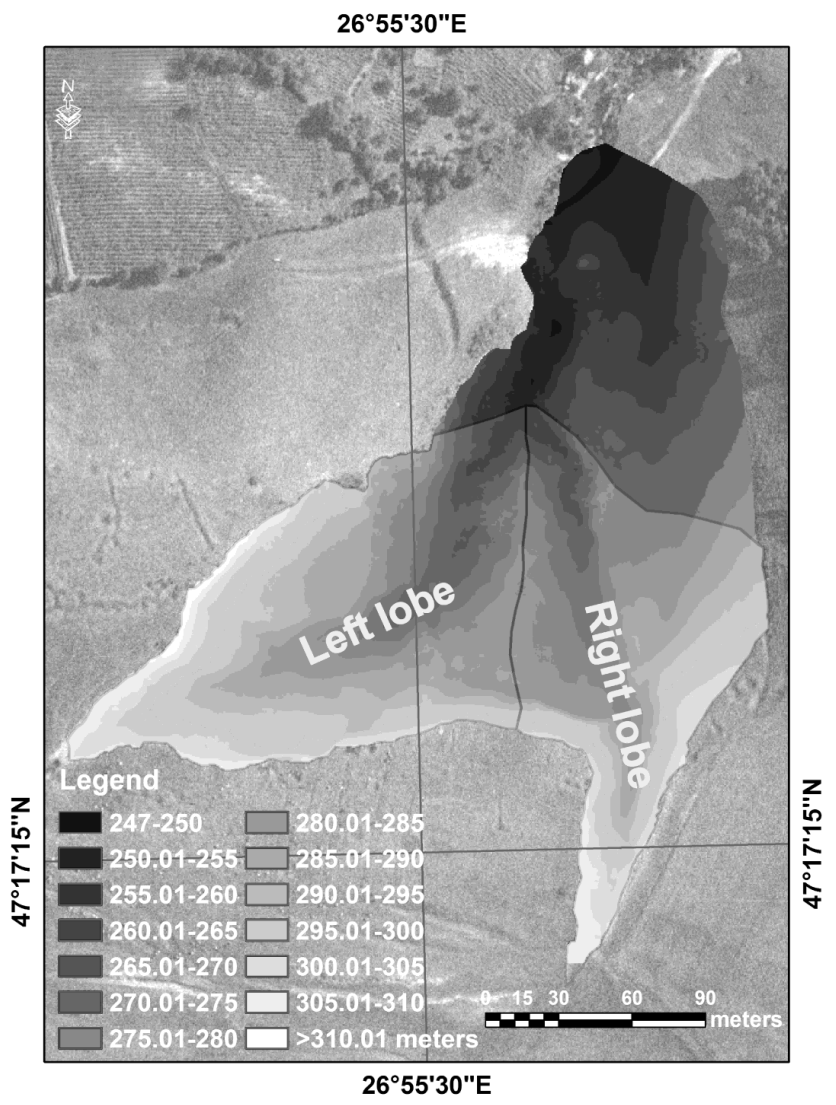

Fig. 20. Morphometric features of the Cucuteni-Baiceni gully.

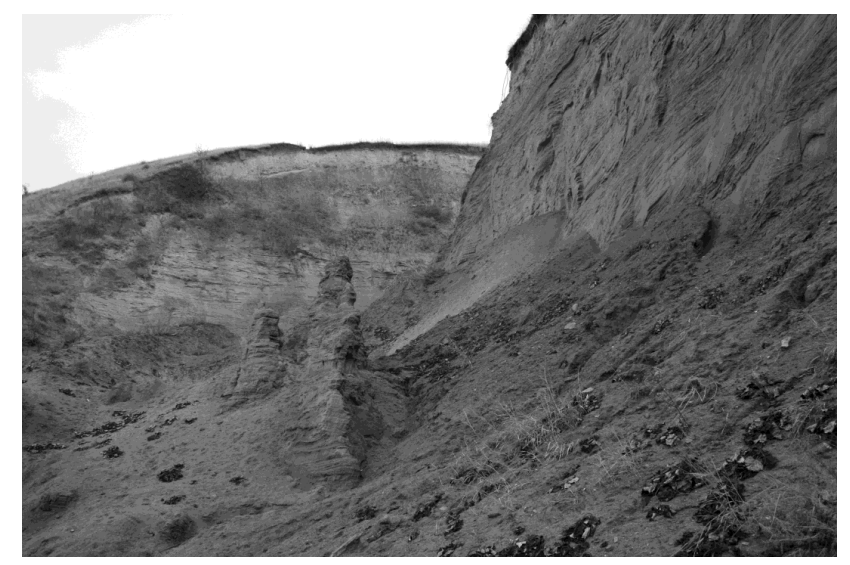

Fig. 21. Massive landfall and development of a ruiniform landscape at the base of the versants.

This material contributed to the local aggradation of the gully (Fig. 19).

The Cucuteni-Baiceni gullies show an increased degree of dynamism, due to a combination of factors, among which the high slope of the slope, brittle material that forms the substrate, the lack of forest and intensive agricultural use of the adjacent shelf, the torrential rainfall, etc., are prominent.

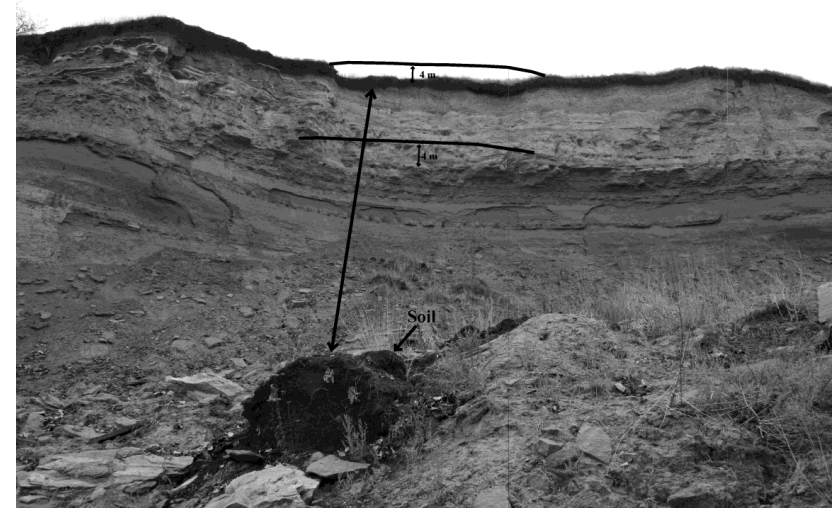

Fig. 22. The fall of the overhanging versant.

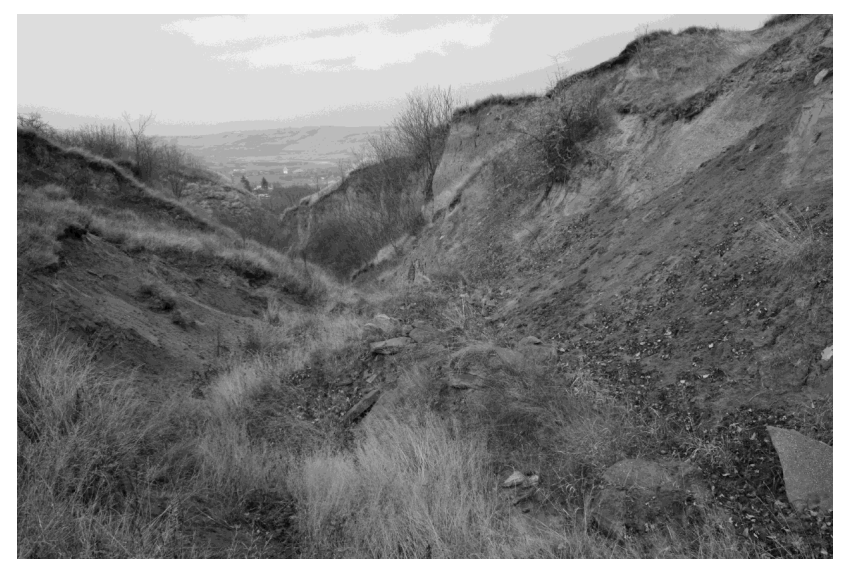

Fig. 23. The depositing of the fallen material in the secondary thalweg.

The volume of the Cucuteni-Baiceni gullies was calculated for each measurement period, but it remains relatively constant as a result of the eroded materials deposited throughout the interior valley. In the period under review, the material was not set in motion by the enclosure gullies (left lobe) (Fig. 20). Between 2008 and 2010, the total volume of the gully increasead from $1.144 \mathrm{~km}^{3}$ to $1.204 \mathrm{~km}^{3}$. A similar growth rate is also registered for the right lobe, where the volume increased from $0.364 \mathrm{~km}^{3}$ to $0.371 \mathrm{~km}^{3}$. An interesting phenomenon occurs in the case of the left lobe: the volume decreases from $0.527 \mathrm{~km}^{3}$ to $0.386 \mathrm{~km}^{3}$ (Table 1). The reduction is due to the aeration of the fallen material and its stagnation within the lobe. When this material with a high porosity will eventually be eliminated, a major increase of the volume is expected.

Unfortunately, in this gully, like many others across the Moldavian Plateau, quick action will not bring about protection because they do not affect a human settlement, but an archaeological site. The history and culture of the Romanian people do not feature on the current agenda of the Romanian government. 
Table 1. Morphometric characteristics of the Cucuteni-Baiceni gully.

\begin{tabular}{cccccccc}
\hline Year & $\begin{array}{c}\text { Total } \\
\text { volume } \\
\left(\mathrm{km}^{3}\right)\end{array}$ & $\begin{array}{c}\text { Volume } \\
\text { of left } \\
\text { lobe } \\
\left(\mathrm{km}^{3}\right)\end{array}$ & $\begin{array}{c}\text { Volume } \\
\text { of right } \\
\text { lobe } \\
\left(\mathrm{km}^{3}\right)\end{array}$ & $\begin{array}{c}\text { Inter } \\
\text {-basin area } \\
\left(\mathrm{km}^{3}\right)\end{array}$ & $\begin{array}{c}\text { Thalweg } \\
\text { of left } \\
\text { lobe }(\mathrm{m})\end{array}$ & $\begin{array}{c}\text { Thalweg } \\
\text { of right } \\
(\mathrm{m})\end{array}$ & $\begin{array}{c}\text { Principal } \\
\text { thalweg } \\
(\mathrm{m})\end{array}$ \\
\hline 2008 & 1.144 & 0.527 & 0.364 & 0.253 & 260.68 & 250.01 & 113.48 \\
2009 & 1.168 & 0.494 & 0.372 & 0.302 & 255.94 & 261.14 & 114.88 \\
2010 & 1.204 & 0.386 & 0.371 & 0.447 & 254.92 & 256.35 & 115.87 \\
\hline
\end{tabular}
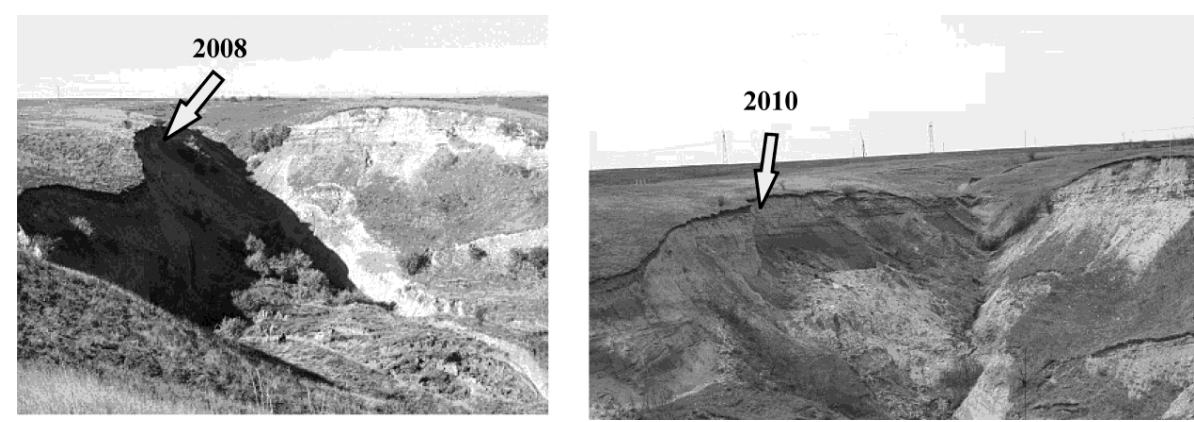

Fig. 24. The slope recession at the top of the secondary gully - between 2008 and 2010.

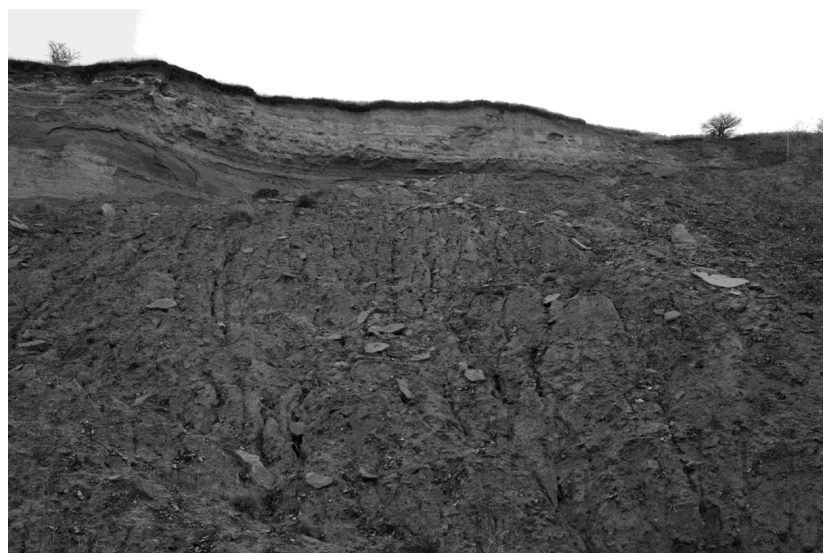

Fig. 25. The erosion furrows running along the deposits recently accumulated in the gully. (A) The right secondary gully; (B) the left secondary gully; and (C) the common gully at the outlet.

The fastest slope recession occurs following landslides and collapses (Fig. 21). The rotational displacement of the materials leads to the development of aeolianly-modelled outliers at the basis of the steep versants.

The most spectacular landfall from between 2008 and 2010 occurred in the spring of the latter year. The collapse of a 4-m-thick cornice overhanging a versant was favoured by the rich precipitations, which strongly dampened a sandyclayish layer that was extremely friable (Fig. 22). One year after the episode, the material present at the base of the versant still displayed the layer of soil detached from the topographical surface. This outlier proves that the subsequent rains were of reduced intensity.

The entire versant now left hanging can collapse at the first strong rain, and the gully's quick rate of advancement could thus increase further more during the period to come. The drought from 2011, the strongest ever recorded in Romania during the recent period, led to a slow-down of the water erosion process. It is for this reason that the material accumulated in the gully, on the slopes or along the thalweg has not been eliminated (Figs. 23 and 24).

The sandy-clayish material accumulated in the gully does not facilitate the quick establishment of vegetation. For this reason, the erosion, either areolar of linear, is quick to take hold. The first erosive landforms generated are erosive furrows and ditches, which produce an incipient "badlands" terrain. The finer particles, the clay and then the sand soils, are the first to be eliminated, after which the harder rocks start to be affected by the erosion. The harder rocks (sandstone slabs, petrified sands and grovel) are heavier and do not drift, but are only repositioned (Fig. 25).

The transport of the material is done in the usual torrential manner, and depends on the amount of water running inside the gully. The quick recession of the slopes and the movement of the alluvial material towards the main current highlights the importance of the interactions between the hydraulic forces acting in the thalweg and at the base of the versants, and the gravitational forces exerting themselves on the material deposited on the slopes. The dislocated material, 


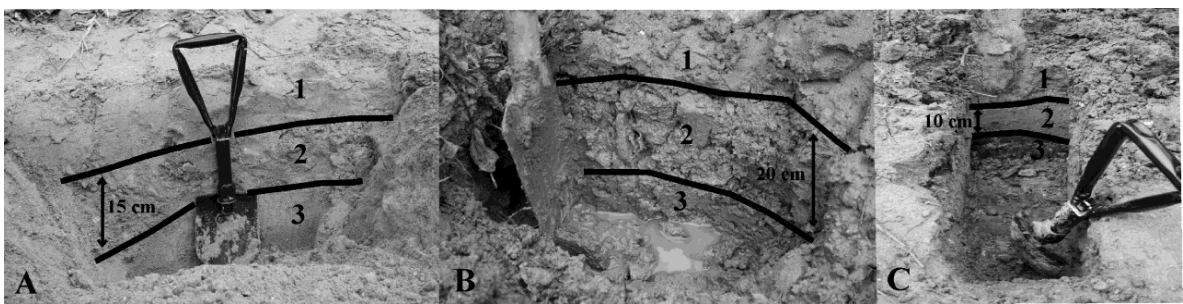

Fig. 26. Profiles of the deposits from the thalweg of the gully.

Table 2. The granulometric distribution in the alluvial horizons from the thalweg.

\begin{tabular}{lcrccc}
\hline Location & Horizon & Clay & Silt & Sand & Gravel \\
\hline The right & 1 & 10.28 & 21.03 & 68.74 & - \\
secondary & 2 & 7.00 & 20.40 & 47.10 & 25.50 \\
gully & 3 & 11.50 & 22.50 & 66.00 & - \\
The left & 1 & 10.65 & 22.10 & 67.25 & - \\
secondary & 2 & 7.20 & 23.30 & 26.20 & 43.30 \\
gully & 3 & 11.20 & 19.50 & 69.30 & - \\
The common & 1 & 17.10 & 24.20 & 58.70 & - \\
gully & 2 & 12.50 & 21.70 & 65.80 & - \\
& 3 & 18.90 & 26.10 & 55.00 & - \\
\hline
\end{tabular}

in tandem with the hydraulic forces, set the typology of the depositing process inside the gully.

The alluvium transported along the thalweg is eliminated at each step that appears along the profile of the bed, and at the outlet, where it forms an alluvial fan.

The torrential, spasmodic, character is borne out by the granulometric distribution of the material from the bed. During the periods with notable torrential activity, the coarser elements are transported, for example gravel. (Fig. 26a and b). The phenomenon is visible on the gully's two secondary arteries, and is absent from the common thalweg, which displays a reduced declivity (Fig. 26c). Towards the outlet, concurrently with the gravel, a layer of coarse sands is also deposited (Table 2).

The accelerated dynamic of the gully necessitated the implementation of a development plan. Set to start in 2012, it mainly aims to preserve an archaeological site of national importance. The reforestation of the plateau from the upper sector of the gully, the draining and quick disposal of the water, and the consolidation of several slope sectors with very active erosion processes are mandatory actions that must be carried out (Fig. 27).

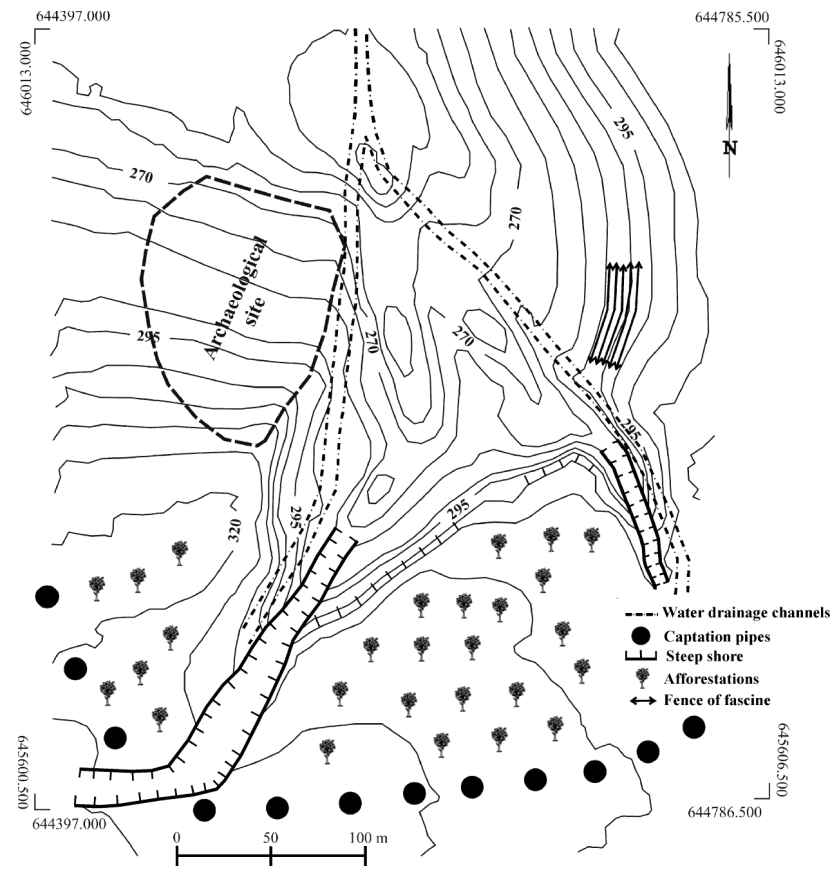

Fig. 27. Proposal for the development of the Cucuteni-Baiceni gully.

\section{Conclusions}

The collecting and interpretation of data obtained using a 3-D scanner is a novel approach in Romanian hydrogeomorphological research. Therefore, some difficulties were encountered in accurately estimating the rate of erosion and accretion, in calculating the volume of displaced material, etc. The 3-D scanner was quite easy to work with, and the data obtained was very accurate. The use of the 3-D scanner, conjointly with the total station, proved that scanner measuring is much faster and that the acquired data is more accurate. The 3-D scanner collects data from throughout the surface of the investigated land form, while the use of only classic equipment presents the risk of harvesting only partial data, i.e. along transversal lines. In the areas between the transversal sections the actual data is absent and a virtual model is used instead. Moreover, using traditional techniques it is almost impossible to collect data from very steep 
walls such as the ones found at the gully from CucuteniBaiceni. Likewise, such measurements would take a very long time to complete, and this constitutes another reason for preferring state-of-the-art equipment for such undertakings.

From this point of view, the geomorphology field will have basic support in using this tool. By using a 3-D scanner, morphometric measurements were made to prepare a topographical map as well as a detailed and accurate three-dimensional model (accuracy $6 \mathrm{~mm}$ ), including dynamic gullies. This is a typical form of relief which contributes to soil degradation and the measures required to stabilize a process of this kind.

For a period of 1.6 years the Cucuteni gully has moved quickly and experienced a degree of warping at an accelerated rate in its drainage. This is the case of strong gullies, given the specific eastern Europe hydroclimatic conditions, substrate and slope. The average regression of the Cucuteni-Baiceni gullies is a much higher $(10 \mathrm{~m} / 1.6$ years, that is $7.5 \mathrm{~m} \mathrm{yr}^{-1}$ ) average in the content of the Moldavian Plateau $\left(1.5 \mathrm{~m} \mathrm{yr}^{-1}\right)$. The gully has attacked the archaeological site, damaging ca. $30 \%$ of its surface. On a historical scale, over a period for 5000 years, the erosion rate is relatively reduced ( 0.07 or $0.11 \mathrm{~m}$ per year). From the end of the Second World War until the present date, the average rate of erosion of the Cucuteni-Baiceni gullies was $0.61 \mathrm{~m}$ per year. An important reason for the acceleration of erosion in recent years has been the intensity of torrential rains. Their growth has been notable, especially in Eastern Romania, where the continental climate experiences significant nuances.

Urgent measures of protection are required to stop farming in the area and hence also the archaeological site of the gullies. There should be emergency afforestation in the related basin slopes, a grazing ban, etc. The 3-D scanner can be used in various fields of physical geography, especially geomorphology, hydrology, cartography, etc. For the moment, appropriate methodology is being developed, using these tools for the entire range of processes that contribute to shaping the current landscape.

Acknowledgements. We extend our thanks to the Geo-archaeology Laboratory within the Faculty of Geography and Geology, Alexandru Ioan Cuza University, Iasi, which provided the instruments and carried out the data-processing.

Edited by: A. Bronstert

\section{References}

Bacauanu, V.: Campia Moldovei. Studiu geomorphologic, Editura Academiei Romane, Bucuresti, 222 pp., 1968.

Bacauanu, V., Barbu, N., Pantazica, M., Ungureanu, A., and Chiriac, D.: Podisul Moldovei. Natura, om, economie, Editura Stiintifica si Enciclopedica, Bucuresti, 347 pp., 1980.

Barnolas, M., Rigo, T., and Llasat, M. C.: Characteristics of 2-D convective structures in Catalonia (NE Spain): an analysis using radar data and GIS, Hydrol. Earth Syst. Sci., 14, 129-139, doi:10.5194/hess-14-129-2010, 2010.
Bitelli, G., Gatta, G., Girelli, V. A., Vittuari, L., and Zanatta, A.: Integrated Methodologies for the 3D Survey and the Structural Monitoring of Industrial Archaeology: The Case of the Casalecchio di Reno Sluice, Italy, Int. J. Geophys., Article ID 874347, Hindawi Publishing Corporation, doi:10.1155/2011/874347, 2011.

Blong, R. J., Graham, O. P., and Veness, J. A.: The role of side wall processes in gully development; some N.S.W. examples, Earth Surf. Proc. Landf., 7, 381-385, 1982.

Böhler, W. and Marbs, A.: 3D Scanning Instruments, CIPA, Heritage Documentation - International Workshop on Scanning for Cultural Heritage Recording, available on-line: http://www. i3mainz.fh-mainz.de (last access: 20 May 2011), 2006.

Boghean, D.: Comunitatile cucuteniene din bazinul Bahlui, Editura Universitatii Stefan cel Mare, Suceava, 248 pp., 2004.

Bornaz, L. and Rinaudo, F.: Terrestrial laser scanner data processing, XXth ISPRS Congress, Turkey, available on-line: http: //www.isprs.org/istanbul2004 (last access: 20 May 2011), 2004.

Bradford, J. M., Piest, R. F., and Spomer, R. G.: Failure sequence of gully headwalls in Western Iowa, Soil Sci. Soc. Am. J., 42, 323-328, 1978.

Branzila, M.: Geologia partii sudice a Campiei Moldovei, Editura Corson, Iasi, 221 pp., 1999.

Bretar, F., Chauve, A., Bailly, J.-S., Mallet, C., and Jacome, A.: Terrain surfaces and 3-D landcover classification from small footprint full-waveform lidar data: application to badlands, Hydrol. Earth Syst. Sci., 13, 1531-1544, doi:10.5194/hess-13-15312009, 2009.

Bull, L. J. and Kirkby, M. J.: Gully processes and modeling, Prog. Phys. Geogr., 21, 354-374, 1997.

Casas, A., Lane, S. N., Yu, D., and Benito, G.: A method for parameterising roughness and topographic sub-grid scale effects in hydraulic modelling from LiDAR data, Hydrol. Earth Syst. Sci., 14, 1567-1579, doi:10.5194/hess-14-1567-2010, 2010.

Cotiuga, V. and Cotoi, O.: Parcul arheologic experimental de la Cucuteni, Cucuteni-Cetatuie - Monografie arheologica, Piatra Neamt, 337-351, 2004.

De Oliveira, M. A. T.: Slope geometry and gully erosion development: Bananal, Sao Paulo, Brazil, Zeitschrift für Geomorphology N.F., 34, 423-434, 1990.

Erhan, E.: Consideratii privind resursele climatice ale Moldovei, Lucrarile Seminarului Geografic "Dimitrie Cantemir", 19-20, 50-57, 2001.

Ernst, J., Dewals, B. J., Detrembleur, S., Archambeau, P., Erpicum, S., and Pirotton, M.: Microscale flood risk analysis based on detailed 2D hydraulic modeling and high resolution geographic data, Nat. Hazards, 55, 181-209, doi:10.1007/s11069-010-9520y, 2010 .

Harvey, A. M.: Process interactions, temporal scales and the development of hillslope gully system: Howgill Fells, northwest England, Geomorphology, 5, 323-344, 1992.

Heede, B. H.: Gully development and Control: The Status of our Knowledge, US Department of Agriculture, Forest Service Research Paper RM-169, 40 pp., 1976.

Ionita, I.: Geomorfologie aplicata, Editura Universitatii Alexandru Ioan Cuza, Iasi, 250 pp., 2000.

Ionita, I.: Gully development in the Moldavian Plateau of Romania, Catena, 68, 133-140, 2006. 
James, T. D., Carbonneau, P. E., and Lane, S. N.: Investigating the effects of DEM error in scaling analysis, Photogramm. Eng. Remote Sens., 73, 67-78, 2007.

Kern, F.: Precise Determination of Volume with Terrestrial 3DLaser scanner, in: Geodesy for Geotechnical and Structural Engineering II, edited by: Kahmen, H., Niemeier, W., and Retscher, G., Berlin, 531-534, 2002.

Lane, S. N.: Living with hazard and risk, Geography, 93, 66-68, 2008.

Lee, I. and Schenk, T.: 3D perceptual organization of laser altimetry data, Int. Arch. Photogramm. Remote Sens., 34, 57-65, 2001.

Leica HDS3000 data sheet: available on-line: http: //www.leica-geosystems.com/hds/en/lgs_5574.htm (last access: 23 April 2011), 2006.

Marzolff, I. and Poesen, J.: The potential of 3D gully monitoring with GIS using high-resolution aerial photography and a digital photogrammetry system, Geomorphology, 111, 48-60, 2009.

Mikoš, M., Vidmar, A., and Brilly, M.: Using a laser measurement system for monitoring morphological changes on the Strug rock fall, Slovenia, Nat. Hazards Earth Syst. Sci., 5, 143-153, doi:10.5194/nhess-5-143-2005, 2005.

Milan, D. G., Heritage, G. L., and Hetherington, D.: Application of a 3D laser scanner in the assessment of erosion and deposition volumes and channel change in a proglacial river, Earth Surf. Proc. Land., 32, 1657-1674, 2007.

Pantazica, M.: Hidrografia Campiei Moldove, Editura Junimea, Iasi, 317 pp., 1974.

Perroy, R. L., Bookhagen, B., Asner, G. P., and Chadwick, O. A.: Comparison of gully erosion estimate using airborn and groundbased LiDAR on Santa Cruz Island, California, Geomorphology, 118, 288-300, 2010.

Phillips, J. D.: Evolutionary geomorphology: thresholds and nonlinearity in landform response to environmental change, Hydrol. Earth Syst. Sci., 10, 731-742, doi:10.5194/hess-10-731-2006, 2006.

Plesoianu, D. and Olariu, P.: Cateva observatii privind inundatiile produse in anul 2008 in bazinul Siretului, Analele Universitatii "Stefan cel Mare" Suceava, Sectiunea Geografie, 19, 69-80, 2010.

Poghirc, P.: Satul din Colinele Tutovei, Editura Stiintifica, Bucuresti, 240 pp., 1972.

Radoane, M., Ichim, I., and Radoane, N.: Gully distribution and development in Moldavia, Romania, Catena, 24, 127-146, 1995.
Radoane, M., Radoane, N., Ichim, I., and Surdeanu, V.: Ravenele, Forme, procese, evolutie, Editura Presa Universitara Clujeana, Cluj-Napoca, 268 pp., 1999.

Radoane, M., Radoane, N., Cristea, I., Popescu, L., Barnoaia, I., Budui, V. and Chiriloaiei, F.: Monitorizarea evolutiei ravenelor test din Podisul Moldovei in perioada 1986-2008, Analele Universitatii Stefan cel Mare, Suceava, serie Geografie, 17, 7-19, 2009.

Romanescu, G.: Siret river basin planning (Romania) and the role of wetlands in diminishing the floods, WIT Transaction on Ecology and the Environment, 125, 439-453, doi:10.2495/WRM090391, 2009.

Romanescu, G. and Nistor, I.: The effect of the July 2005 catastrophic inundations in the Siret River's Lower Watershed, Romania, Nat. Hazards, 57, 345-368, doi:10.1007/s11069-010-96173, 2011 .

Romanescu, G., Romanescu, G. T., Stoleriu, C., and Ursu, A.: Inventarierea si tipologia zonelor umede si apelor adanci din Podisul Moldovei, Editura Terra Nostra, Iasi, 244 pp., 2008.

Romanescu, G., Jora, I., and Stoleriu, C.: The most important high floods in Vaslui river basin - causes and consequences, Carpathian J. Earth Environ. Sci., 6, 119-132, 2011a.

Romanescu, G., Stoleriu, C., and Romanescu, A. M.: Water reservoirs and the risk of accidental flood occurrence, Case study: Stanca-Costesti reservoir and the historical floods of the Prut river in the period July-August 2008, Romania, Hydrol. Process., 25, 2056-2070, doi:10.1002/hyp.7957, 2011b.

Ursulescu, N.: Donées récentes concernant l'histoire des communautés énéolithique de la civilisation Cucuteni, Acta Terrae Septemcastrensis Journal, 5, 79-113, 2006.

Vandaele, K., Poesen, J., Govers, G., and van Wesenael, B.: Geomorphic threshold conditions for ephemeral gully incision, Geomorphology, 16, 161-173, doi:10.1016/0169-555x(95)00141-Q, 1996.

Vosselman, G. and Dijkman, S.: 3D Building Model Reconstruction From Point Clouds and Ground Plans, International Archives of Photogrammetry and Remote Sensing, 34, 37-44, 2001

Xie, H. and Jia, H.: The Development of 3D Laser Scanning Technique and Its Applications in Land Reclamation, Information Engineering and Electronic Commerce (IEEC), 2, 1-4, doi:10.1109/IEEC.2010.5533250, 2010. 